\title{
Metacognitive Awareness in Teaching and Teaching Competency: A Survey on Student Teachers at Secondary Level
}

\author{
Seema Gopinath
}

Metacognition has now been emerged as an important part of teacher preparation programs. The term metacognition was introduced by psychologists to refer to knowledge about and control over thinking and learning activities.(Flavell, 1976). Metacognition involves at least two components (1) an awareness of the skills, strategies and resources needed to perform a task effectively- knowing what to do and (2) the ability to use self- regulatory mechanisms to ensure the successful completion of the task- knowing how and when to do the what. The strategies in the first component 'knowing what to do' include identifying the main idea, rehearsing information forming association and images using mnemonics, organizing new material to make it easier to remember, applying test taking techniques, out lining and note taking.

The regulatory mechanisms- the second component, knowing how and when-include checking to see if you understand, predicting outcomes, evaluating the effectiveness of an attempt at a task, planning the next move, testing strategies, deciding how to apportion time and revising or switching to other strategies to overcome any difficulties encountered (Baker, 1994 \& Brown, 1978). The use of these regulatory mechanisms is known as cognitive monitoring (Flavell, 1985).

Several researches offer evidence that metacognition is teachable (Cross\& Paris,1988; Dignath et al.,2008). Metacognitive skills and beliefs about learning have consequences for student's learning and performance. Teaching metacognition- introducing these new skills and beliefs and giving students practice at applying them- improves student's learning (Lovett, 2008). Metacognition is a special type of knowledge and ability that develops with personal experience and with schooling. It is a recursive loop with cognitive development in that it produces and is a product of cognitive development (Paris and Winograd, 1990). Metacognition plays an important role in communication, reading comprehension, language acquisition, problem solving and personality development (Flavell, 1979).

Teacher competencies are outcome- based method for assessing teacher performance. They define key characteristics of successful teachers without prescribing any specific curriculum or instructional practices. Teaching competency refers to "the right way of conveying units of knowledge, application and skills to students." The right way here includes knowledge of content, processes, methods and means of conveying content. Competent teachers would also create classroom conditions and climate which are conducive for student learning. Teachers having good metacognitive teaching competency can help their students to develop metacognitive ability in them.

Teacher education is going through an unprecedented period of change. Across the world, the number and quality of teachers are becoming a key policy concern. This phenomenon affects the richer industrialized nations and those in the process of developing stronger economic infrastructure. Ensuring adequate supply of higher quality teachers is therefore a challenge, as is the expanding task of providing coherent, career- long, professional development, opportunity for teachers. As knowledge increases and technologies emerge, so the status of teachers has to adapt. The scale of demand for teacher education is large. In this context, it is clear that the institutions of teacher education created in the twentieth century will be unable to meet the demands of the twenty first. Any educational effort loses its vitality if it does not give adequate attention and importance to the teachers, one of the most important pillars of education. In this context the investigator made an attempt to find the existing level of Metacognitive Awareness in Teaching and Metacognitive Teaching Competency of student teachers at secondary level and also to find out whether there exists any relationship between the two variables.

I.

Objectives

1. To compare the level of Metacognitive Awareness in Teaching among student teachers at secondary level based on

(a) Type of Management of the Institution (Government- Aided/ Unaided)

(b) Locale of Institution(Rural/ Urban)

(c) Educational Qualification(Graduate/ Post Graduate)

(d) Subject of Study (Science/Language)

2. To compare the level of Metacognitive Teaching Competency among student teachers at secondary level based on

(a) Type of Management of the Institution(Government- Aided/ Unaided) 
(b) Locale of Institution(Rural/ Urban)

(c) Educational Qualification(Graduate/ Post Graduate)

(d) Subject of Study( Science/Language)

3. To find out whether there is any relationship between Metacognitive Awareness

in Teaching and Metacognitive Teaching Competency of student teachers at secondary level for the total sample and the relevant sub samples.

\section{II.}

Methodology

The investigator used survey method for finding out the existing level of Metacognitive Awareness Inventory using Metacognitive Awareness Inventory in Teaching and also the existing level of Metacognitive Teaching Competency using Metacognitive Teaching Competency Inventory. The data were collected randomly from a sample of 500 student teachers at secondary level based on type of management of the institution, locale of institution, educational qualification and subject of study of student teachers from different districts of Kerala using stratified random sampling technique.

III.

Analysis And Interpretation

\section{Comparison of Metacognitive Awareness in teaching among different sub groups.}

The Arithmetic Mean and Standard Deviation of sub samples based on type of institution, locale of institution, academic qualification of student teachers and subject of study of student teachers for scores on Metacognitive Awareness in Teaching were found out and tested the significance of difference between mean scores for large independent sample using critical ratio. The details are given in Table 1.

Table 1 Comparison of scores on Metacognitive Awareness in Teaching of student teachers at secondary level. (Consolidated)

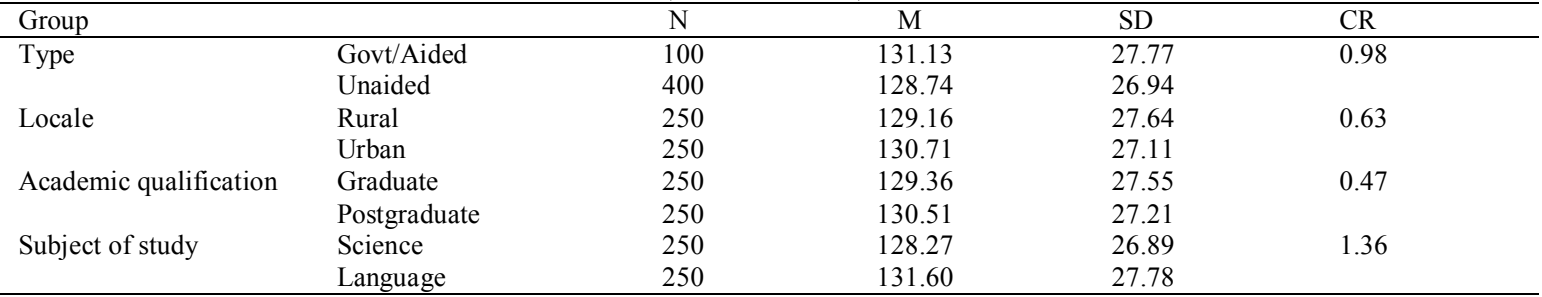

The arithmetic mean of all the sub samples revealed that the student teachers are having an average level of Metacognitive Awareness in Teaching. The critical ratio for Metacognitive Awareness in Teaching on the basis of type of management, locale, academic qualification and subject of study are $0.98,0.63,0.47$ and 1.36 respectively. These values are less than the tabled value 1.96 at 0.05 level of significance. Thus there was no significant difference in the scores on Metacognitive Awareness in Teaching of student teachers in Government- aided and Unaided Teacher Education Colleges, Rural and Urban, student teachers with Graduate and Post graduate degree and for student teachers studying for Science and Language subjects at 0.05 level of significance.

Comparison of Metacognitive Teaching Competency among different sub groups.

The Arithmetic Mean and Standard Deviation of sub samples based on type of institution, locale of institution, academic qualification of student teachers and subject of study of student teachers for scores on Metacognitive Teaching Competency were found out and tested the significance of difference between mean scores for large independent sample using critical ratio. The details are given in Table 2.

Table 2 Comparison of scores on Metacognitive Teaching Competency of student teachers at secondary level.

\begin{tabular}{|c|c|c|c|c|c|}
\hline Group & & $\mathrm{N}$ & $\mathrm{M}$ & $\mathrm{SD}$ & $\mathrm{CR}$ \\
\hline \multirow{2}{*}{ Type } & Govt/Aided & 100 & 133.28 & 21.08 & 1.34 \\
\hline & Unaided & 400 & 130.14 & 20.13 & \\
\hline \multirow[t]{2}{*}{ Locale } & Rural & 250 & 129.76 & 19.31 & 0.86 \\
\hline & Urban & 250 & 131.23 & 18.67 & \\
\hline \multirow[t]{2}{*}{ Academic qualification } & Graduate & 250 & 132.06 & 17.94 & 0.44 \\
\hline & Postgraduate & 250 & 131.33 & 18.85 & \\
\hline \multirow[t]{2}{*}{ Subject of study } & Science & 250 & 133.18 & 21.85 & 1.92 \\
\hline & Language & 250 & 129.52 & 20.91 & \\
\hline
\end{tabular}

The arithmetic mean of all the sub samples revealed that the student teachers are having an average level of Metacognitive Teaching Competency. The critical ratio for Metacognitive Teaching Competency on the basis of type of management, 
locale, academic qualification and subject of study are 1.34, 0.86, 0.44 and 1.92 respectively. These values are less than the tabled value 1.96 at 0.05 level of significance. Thus there was no significant difference in the scores on Metacognitive Teaching Competency of student teachers in Government- aided and Unaided Teacher Education Colleges, Rural and Urban, student teachers with Graduate and Post graduate degree and for student teachers studying for Science and Language subjects at 0.05 level of significance.

\section{Correlation between Metacognitive Awareness in Teaching and Metacognitive Teaching Competency among student teachers at secondary level.}

The relationship between the two variables was found out using the Pearson's Product Coefficient of Correlation Technique. The obtained values are presented in Table 3.

Table 3 Correlated values between Metacognitive Awareness in Teaching and Metacognitive Teaching Competency for the total sample and relevant sub samples

\begin{tabular}{|c|c|c|c|}
\hline Group & Category & $\mathrm{N}$ & Correlation \\
\hline \multirow{2}{*}{$\begin{array}{c}\text { Type of } \\
\text { management }\end{array}$} & Total & 500 & 0.831 \\
\cline { 2 - 4 } & Govt/ Aided & 100 & 0.893 \\
\hline \multirow{2}{*}{ Locale } & Unaided & 400 & 0.901 \\
\cline { 2 - 4 } & Rural & 250 & 0.860 \\
\hline \multirow{2}{*}{$\begin{array}{c}\text { Educational } \\
\text { Qualification }\end{array}$} & Graduate & 250 & 0.874 \\
\cline { 2 - 4 } & Post Graduate & 250 & 0.913 \\
\hline Subject of study & Science & 250 & 0.946 \\
\cline { 2 - 4 } & Language & 250 & 0.874 \\
\hline
\end{tabular}

From Table 3 , it is clear that there exists a very high positive correlation between the Metacognitive Awareness in Teaching and Metacognitive Teaching Competency with respect to total sample and each category in sub samples.

\section{Conclusion}

The study revealed that the Metacognitive Awareness in Teaching of the student teachers is at an average level. There is no significant difference in the mean scores of Metacognitive Awareness in Teaching of the student teachers with respect to each sub sample. Also the Metacognitive Teaching Competency of the student teachers at secondary level is also at an average level and there is no significant difference in the mean scores of Metacognitive Teaching Competency of the student teachers with respect to each sub sample. The coefficient of correlation between each category of the sub samples of the two variables revealed that there is a very high positive correlation between the Metacognitive Awareness in Teaching and Metacognitive Teaching Competency. Thus it can be interpreted that Metacognitive Awareness in Teaching can promote Teaching Competencies. Hence necessary steps must be taken for including metacognition in teacher education curriculum and also for the provision of practicing metacognitive skills. This in turn help teachers to create classroom conditions and climate which are conducive for student learning and for developing the teaching competencies such as content knowledge, instructional planning, student motivation, presentation and communication skills, evaluation competencies and classroom management skills. When the teacher acquires all these dimensions in a reasonable extent, it is the manifestation of these in an integrated manner that makes him effective in the classroom climate.

\section{References}

[1]. Best, J.W., \& Khan, J.V.(1989). Research in Education. New Delhi: Prentice Hall of India.

[2]. Baker, L., \& Brown, A. L. (1984). Metacognitive skills and reading. In P.D. Pearson, M.Kamil, R.Barr \& P. Mosenthal (Eds.), Handbook of research in reading. (vol.1, pp.353-395). New York: Longman.

[3]. Cross, D. R., \& Paris, S. G. (1998). Developmental and instructional analysis of children's metacognition and reading comprehension. Journal of Educational Psychology, 80: 131- 142.

[4]. Dignath, C., Buettner, G.,\& Langfeldt, H. (2008). How can primary school students learn self- regulated learning strategies most effectively? A meta- analysis on self- regulation training programs. Educational Research Review, 3.2, p.p $101-129$

[5]. Flavell, J. H. (1979). Metacognition and Cognitive monitoring: A new area of cognitive- developmental enquiry, American Psychologist, 34, 906-911

[6]. Flavell , J. H. (1976). Metacognitive aspects of problem solving in L.B. Resnick (ed). The nature of intelligence. Hillsdale. NJ: Lawrance Erlbaum Associates.

[7]. Flavell, J. H. (1985). Cognitive development. NJ : Prentice- hall Englewood Cliffs.

[8]. Garrett, Henry E. (1981). Statistics in psychology and education. New York: David McKay Company.

[9]. Lovett. (2008). Teaching meatcognition. Presentation to the Educause Learning Initiative Annual Meeting

[10]. Paris, S. G., \& Winograd, P.W (1990). How metacognition can promote academic learning and instruction. In B. J. Jones \& L. Idol (Eds.), Dimensions of thinking and cognitive instruction. Pp. 15- 51. Hillsdale, NJ: Lawrence Erlbaum Associates.

[11]. Saravana Kumar, A. R.(2005). Role of metacognitive orientation and teaching competency in enhancing students achievement. Paper presentation in National Seminar. Alagappa University, Karaikudy. 